\title{
ПСИХІЧНІ І ПСИХОТИЧНІ РОЗЛАДИ ТА ЕФЕКТИВНІСТЬ ВААРТ У ВІЛ-ІНФІКОВАНИХ СПОЖИВАЧІВ ІН'ЄКЦІЙНИХ НАРКОТИКІВ
}

\author{
Запорізька медична академія післядипломної освіти МОЗ України
}

У ВІЛ-інфрікованих споживачів ін'єкційних наркотиків (СIH) часто (35-50 \%) діагностуються супутні психічні розлади. Замісна підтримувальна терапія (ЗПТ) метадоном і бупренорфіном є потужним елементом профрілактики ВІЛ, а високоактивна антиретровірусна терапія (ВАAPT) - обов'язковою складовою комплексної медичної допомоги ВІЛ-інфрікованим. Мета дослідження - оцінка впливу психічних та психотичних розладів на ефрективність ВААРТ у хворих на ВІЛінфрекцію СІН при проведенні ЗПТ. У дослідження включено 33 хворих на ВІЛ-інфрекцію СІН, в яких до початку ЗПТ, ВААРТ і через 24 тиж. лікування проводилася оцінка ступеня психічних й психотичних розладів за шкалами BPRS і MADRS. Вірусологічна ефрективність ВАAРТ визначалася на 24-му тиж. лікування.

На тлі проведення ЗПТ до початку ВААРТ у всіх хворих відмічене зниження інтенсивності психотичних і депресивних розладів, що через 24 тиж. прийому BAAPT склало 12 балів за BPRS i 6 балів за MADRS. Ha фоні ВААРТ через 24 тиж. у 25 (75,8 \%) хворих досягнуто повну супресію ВІЛ, у 8 (24,2 \%) осіб зареєстровано вірусологічну неефективність ВААРТ. Ступінь психотичних і психічних розладів у хворих з вірусологічною неефективністю до початку ВААРТ був значимо вищий та склав 43 (41,5-46,5) бали за шкалою BPRS і 16 (14-17,5) - за шкалою MADRS. Більшість пацієнтів з психотичними розладами (>41 балу за BPRS) i/чи депресивними порушеннями (>14 балів за MADRS) не досягли вірусологічної ефективності через 24 тижні ВААРТ. На фроні ЗПТ у ВІЛ-інфрікованих СІH знижується ступінь психотичних і депресивних розладів, що позитивно впливає на вірусологічну ефективність ВААРТ. Низьку вірусологічну ефективність ВААРТ можна прогнозувати у хворих на ВІЛ-інфекцію CIH при оцінці >41 балу за BPRS i/чи >14 балів за MADRS.

Ключові слова: ВІЛ-інфекція, ВАAРT, CD4-лімфроцит, метадон, бупренорфрін, споживачі ін'єкційних наркотиків.
Сучасний стан розвитку епідемічного процесу ВІЛінфекції в країні характеризується значним поширенням ВІЛ серед різних контингентів населення, в першу чергу серед осіб, які належать до груп високого ризику інфрікування; нерівномірним поширенням ВІЛ-інфекції по різних територіях України; зміною домінуючих шляхів передачі ВІЛ.

Незважаючи на багаторічну тенденцію до зниження, актуальність парентерального шляху передачі при ін'єкційному введенні наркотичних препаратів в Україні залишається високою - 26,6 \% у 2015 році. СІН є соціальною групою, яка все ще залишається найбільш вразливою як середовище, де активно розповсюджується ВІЛ. Кумулятивна частка СІH серед всіх офріційно зареєстрованих випадків ВІЛ-інфекції складає $68 \%$. Це підтримує розвиток епідемії і не дозволяє взяти її під повний контроль [1].

У ВІЛ-інфрікованих СІН часто (35-50 \%) діагностуються супутні психічні розлади. Серед вкрай різноманітних психічних порушень, що відзначаються у ВІЛ-інфікованих споживачів ін'єкційних наркотиків, провідне місце посідають депресивні синдроми. Масштабне скринінгове дослідження виявило, що протягом останнього року більше 30 \% ВІЛ-позитивних СІН відмітили у себе симптоми депресії. Вони можуть бути проявом маніакальнодепресивного психозу (так звані великі депресії, циклотимії) або бути обумовленими відміною опіоїдів (ангедонія в опіоїдних наркозалежних). Друге місце посідають тривожні розлади. Пацієнти відчувають немотивовану тривогу, обсесивні думки, фоббії. На цьому тлі буває важко встановити продуктивний стосовно організації лікування контакт [2].

Оцінка ступеня психічних і психотичних розладів проводиться за шкалою Монтгомері-Асберга (MADRS) та Короткою психіатричною оцінковою шкалою (BPRS), які належать до числа об'єктивних клінічних інструментів, широко застосовуваних у сучасній медицині. MADRS і BPRS прості і зручні в застосуванні, використовувати їх можуть як психіатри, так і лікарі загальної практики, 
психологи. Застосування шкали Монтгомері-Асберг, також як і Короткої психіатричної оцінкової шкали, засноване на клінічному інтерв'ю, коли дослідник задає випробуваному наведені в бланку шкали питання.

Високий ступінь валідності та широкі можливості до застосування стосовно пацієнтів різного профрілю патології служили критеріями вибору даних шкал як інструмента дослідження [3].

В сучасних умовах одним з ефективних методів лікування наркозалежності є проведення 3ПТ, особливо для ВІЛ-інфікованих СІН, які потребують проведення BAАРТ. Для замісної терапії рекомендується використання двох препаратів - метадону чи бупренорфіну. Проведені дослідження довели, що участь в програмах ЗПТ значно підвищує утримання пацієнтів на лікуванні; суттєво зменшує ризиковану та кримінальну поведінку, ймовірність смерті внаслідок передозування, вживання нелегальних опіоїдів, ризик рецидиву та повернення до вживання нелегальних наркотиків і $є$ предиктором задовільної прихильності до ВААРТ [4-6].

Метою нашого дослідження було оцінити вплив психічних та психотичних розладів на ефективність BAAРТ у хворих на ВІЛ-інфекцію СІН у динаміці спостереження на фроні проведення замісної підтримувальної терапії; оцінити можливість застосування шкал депресії у ВІЛ-позитивних пацієнтів - споживачів ін'єкційних наркотиків.

\section{Пацієнти і методи}

У дослідження було включено 33 хворих на ВІЛінфекцію $\mathrm{CIH}$, які перебували на обліку в Запорізькому обласному центрі профрілактики і боротьби з ВІЛ/СНІД й раніше не отримували ВААРТ та не мали активних опортуністичних інфекцій.

Середній вік хворих склав 37 років (від 24 до 52). Жінок було 8 (24,5 \%), чоловіків 25 (75,5 \%), середній строк споживання наркотичних речовин - 14 років (від 2 до 26). Серед обстежених хворих у 2 (6,0 \%) пацієнтів діагностовано I клінічну стадію ВІЛ-інфекції, у 2 (6,0 \%) - II, у 14 (42,5 \%) - III, у 15 (45,5 \%) - IV клінічну стадію (відповідно до класифікації ВОО3, 2006). Середній строк перебування на диспансерному обліку з моменту виявлення ВІЛ-інфекції до початку ВААРТ склав 6 років (від 1 до 16 років). 315 хворих з IV клінічною стадією у 13 (86,5 \%) основним СНІДіндикаторним захворюванням в анамнезі був туберкульоз.

Для оцінки ступеня психотичних розладів у динаміці спостереження використовувалася Коротка психіатрична оцінкова шкала (BPRS). Шкала містить 18 пунктів, які оцінюють той чи інший тип продуктивної симптоматики за 7-бальною шкалою: від 0 - відсутній до 7 - вкрай гостро виражений симптом. Інтерпретація результатів проводить- ся шляхом підсумовування 18 оцінок для визначення загальної нездатності до адаптації. Для BPRS з низьким рівнем порушень можна вважати загальний бал до 40, середнім - 40-60, високим - понад 60. Оцінка депресії проводилася за допомогою шкали Монтгомері-Асберга. Шкала MADRS розроблена для швидкої оцінки тяжкості депресії і її динаміки в процесі терапії. Вона містить 10 основних ознак депресії, які оцінюються за 6-бальною системою. Інтерпретація результатів проводиться шляхом підсумовування: від 0 до 6 балів - відсутність депресивного епізоду; від 7 до 19 балів - малий депресивний епізод; від 20 до 34 балів - помірний депресивний епізод; понад 35 балів - великий депресивний епізод. Існуючі сьогодні критерії ремісії за результатами заповнення шкали MADRS досить волюнтаристичні, проте більшість авторів сходиться на думці, що ремісія відповідає редукції симптоматики до 10 балів і менше [7].

Оцінка ступеня психотичних та психічних розладів проводилася до початку ЗПТ і ВААРТ та через 24 тиж. проведення високоактивної антиретровірусної терапії.

Після оцінки ступеня психічних і психотичних розладів пацієнти були включені в програму ЗПт з використанням метадону - 22 (66,0 \%) особи чи бупренороріну - 11 (34,0 \%). Призначення ЗПт проводилося в три етапи: індукції, стабілізації і підтримки. Початкова доза метадону була у межах 20-30 мг, бупренорфіну 4 мг із поступовим збільшенням дози. Нарощували дозу метадону по 5 мг та бупренорфіну по 2 мг щоденно на першому тижні лікування. У фразу стабілізації (2-6-й тиждень) дозу поступово продовжували нарощувати, в середньому не вище 20 мг метадону та не більше 8 мг бупренорфіну протягом тижня. У підтримувальній фразі лікування середня доза метадону склала 110 мг, бупренорфіну - 12 мг.

Після включення в програму ЗПТ всім хворим була призначена ВААРТ відповідно до клінічного протоколу антиретровірусної терапії ВІЛ-інсрекції у дорослих та підлітків [8]. Середній строк перебування в програмі ЗПт до початку ВААРТ склав 23,7 міс. (від 1 до 60) і залежав від швидкості прогресування імуносупресії і появи інших показань для призначення ВААРТ.

Схеми ВААРТ, які отримували наші пацієнти, представлені в таблиці 1 .

Визначення рівня вірусного навантаження HIV-RNA у крові проводилось методом полімеразної ланцюгової реакції з використанням тест-систем Abbott Realtime ${ }^{\text {TM }}$ HIV-1 на ампліфікаторе Abbott Real-time m2000rt (США). Рівень вірусного навантаження HIV-RNAу хворих визначали перед призначенням BAAPT та через 24 тиж. лікування. До початку BAAPT вірусне навантаження HIV-RNA було досліджено у 27 хворих, середній рівень склав 4,89 (4,1-5,2) lg копій/мл. 
Таблиця 1

Схеми ВААРТ, які отримували хворі на ВІЛ-інфекцію

\begin{tabular}{|l|c|c|}
\hline \multirow{2}{*}{\multicolumn{2}{|c|}{ Схема }} & \multicolumn{2}{|c|}{ Кількість хворих } \\
\cline { 2 - 3 } & абс. & $\%$ \\
\hline AZT/3TC+EFV & 17 & 51,5 \\
\hline TDF/3TC+EFV & 5 & 15,1 \\
\hline AZT/3TC+LPV/rtv & 4 & 12,1 \\
\hline d4T/3TC+EFV & 2 & 6,1 \\
\hline AZT/3TC+NVP & 2 & 6,1 \\
\hline TDF/FTC+EFV & 3 & 9,1 \\
\hline Pазом & 33 & 100,0 \\
\hline
\end{tabular}

Статистичну обробку отриманих даних проводили 3 використанням комп'ютерної програми STATISTICA 6.0. Для визначення нормальності розподілу ознак використовували графрічний метод, критерій Ліллієсорса i W-критерій Шапіро-Уілка. Більшість ознак не мали нормального розподілу, тому дані представлені у вигляді Me (IQR), де Me - медіана, IQR - інтерквартільний розмах (нижній квартільверхній квартіль). Для порівняння незалежних груп використовували U критерій Мана-Уітни, для порівняння залежних груп - критерій Вілкоксона. Кореляційний аналіз виконували методом рангових кореляцій Спірмена. Розходження вважали статистично значимими при $p<0,05$.

\section{Результати досліджень та їх обговорення}

Динаміка ступеня психотичних і психічних розладів у хворих на ВІЛ-інфекцію в динаміці проведення ЗПТ та ВААРТ представлена в таблиці 2.

Таблиця 2

Оцінка ступеня психотичних та психічних розладів за шкалою BPRS та шкалою MADRS у хворих в динаміці проведення ЗПТ і ВААРТ

\begin{tabular}{|l|c|c|c|}
\hline Шкала & ЗПт & $\begin{array}{c}\text { Початок } \\
\text { ВААРТ }\end{array}$ & 24 тижні ВАAРT \\
\hline BPRS & $34(31-45)$ & $27(21-41)^{\star}$ & $15(12-30)^{\star},{ }^{* *}$ \\
\hline MADRS & $14(12-17)$ & $9(7-14)^{*}$ & $8(6-12)^{\star}$ \\
\hline
\end{tabular}

Примітки: * - значуща розбіжність 3 початковим рівнем за критерієм Вілкоксона $(p<0,05)$; ** - значуща розбіжність 3 24 тижнями за критерієм Вілкоксона $(p<0,05)$.

До початку ЗПТ середня оцінка ступеня психотичних розладів за шкалою BPRS склала 34 (31-45) бали. При цьому у 18 (55\%) хворих зареєстрований низький рівень (менше 40 балів за BPRS), у 15 (45 \%) хворих - середній рівень порушень із загальним балом від 40 до 60 за BPRS. Високого рівня психотичних порушень (більше 60 балів за шкалою BPRS) у наших хворих не було.
При проведенні оцінки тяжкості депресії за допомогою шкали Монтгомері-Асберга середній рівень психічних порушень відповідав 14 (12-17) балам. У 5 (15 \%) хворих не виявлені депресивні розлади (менше 6 балів за MADRS ), у 25 (76 \%) осіб зафіксований малий депресивний епізод (від 7 до 19 балів за MADRS) та у 3 (9\%) хворих спостерігався помірний депресивний епізод (від 20 до 34 балів за MADRS). Пацієнти з великим депресивним епізодом (оцінка за шкалою MADRS більше 35) були відсутні.

На фроні проведення ЗПТ до початку ВААРТ у всіх хворих відмічалося зниження інтенсивності психотичних розладів - до 27 (21-41) балів за BPRS, середній показник зниження склав 7 балів. У 21 (64\%) хворого мав місце низький рівень порушень, і у 12 (36 \%) хворих був зареєстрований середній рівень порушень. При оцінці психотичних розладів через 24 тиж. прийому ВААРТ продовжувалось подальше зниження показника до 15 балів, і загальний середній показник зниження склав 12 балів. У 30 (91\%) хворих мав місце низький рівень порушень, і у 3 (9 \%) хворих був зареєстрований середній рівень порушень.

Інтенсивність депресії на фроні лікування агоністами опіоїдів до початку ВААРТ і через 24 тиж. прийому антиретровірусної терапії значимо знизилася до 9 (7-14) і 8 (6-12) балів за MADRS відповідно, та загальний середній показник зниження склав 5 балів. У 9 (27\%) хворих спостерігався малий депресивний епізод, у решти - ремісія, що відповідає редукції симптоматики 6 балів і менше за MADRS.

Через 24 тиж. ВААРТ у 25 (75,8 \%) хворих була досягнута повна супресія ВIЛ (HIV-RNA<50 копій/мл). У 8 (24,2 \%) пацієнтів була зареєстрована вірусологічна неефективність ВААРТ. Середній рівень вірусного навантаження HIV-RNA у пацієнтів 3 вірусологічною невдачею склав $2,06(1,75-3,49) \mathrm{lg}$ копій/мл. Показники психотичних та психічних розладів за шкалами до початку лікування залежно від вірусологічної ефрективності через 24 тиж. ВААРТ наведено в таблиці 3.

Таблиця 3

Ступінь психотичних і психічних розладів за шкалою BPRS та шкалою MADRS у хворих на ВІЛ-інфекцію до початку ВААРТ залежно від рівня вірусного навантаження HIV-RNA на 24-му тижні лікування

\begin{tabular}{|l|c|c|}
\hline шкала & $\begin{array}{c}\text { HIV-RNA>50 копій/мл } \\
24 \text { тижні APT }(n=8)\end{array}$ & $\begin{array}{c}\text { HIV-RNA<50 копій/мл } \\
24 \text { тижні APT }(n=25)\end{array}$ \\
\hline BPRS & $43(41,5-46,5)$ & $22(19-30)^{\star}$ \\
\hline MADRS & $16(14-17,5)$ & $8(6-9)^{\star}$ \\
\hline
\end{tabular}

Примітка. * - значиме розходження за U критерієм МанаУітни $(p<0,05)$. 
Ступінь психотичних і психічних розладів за шкалами у 8 хворих з вірусологічною неефективністю до початку призначення ВААРТ був значимо вищий, ніж у хворих, які досягли повної вірусної супресії, і склав 43 $(41,5-46,5)$ бали за шкалою BPRS і $16(14-17,5)$ балів за шкалою MADRS. У хворих з вірусологічною ефективністю BAAPT (HIV-RNA<50 копій/мл) на 24-му тижні, бал оцінки за шкалами BPRS та MADRS склав 22 (19-30) і 8 (6-9) відповідно.

Усі хворі з низьким рівнем психотичних розладів і відсутніми депресивними порушеннями досягли повної вірусної супресії, тоді як більшість пацієнтів з психотичними розладами (більше 41 балу за BPRS) i/чи депресивними порушеннями (більше 14 балів за MADRS) не досягли вірусологічної ефрективності на 24-му тижні ВААРТ.

Таким чином, оцінка ступеня психотичних розладів за шкалою BPRS і ступеня депресії за шкалою MADRS до призначення ВААРТ у хворих на ВІЛ-інфекцію споживачів ін'єкційних наркотиків може використовуватися для прогнозування вірусологічної ефективності ВААРТ на 24-му тижні лікування. При оцінці до початку ВААРТ за шкалою BPRS більше 41 балу і/чи оцінці за шкалою MADRS більше 14 балів можна прогнозувати вірусологічну неефективність ВААРТ на 24-му тижні лікування.

Проведене дослідження свідчить, що застосування ЗПТ у хворих на ВІЛ СІН істотно знижує ступінь психотичних розладів та депресивних станів і підвищує вірусологічну ефективність ВААРТ, що може бути пов'язано із значним підвищенням прихильності до лікування у зазначеної категорії хворих з психічними та поведінковими розладами внаслідок споживання психоактивних речовин з вмістом опіоїдів [9, 10].

Замісна підтримувальна терапія $€$ одним із еорективних методів лікування наркотичної залежності та забезпечення високої прихильності до ВААРТ. Відомо, що пацієнти, які активно вживають психоактивні речовини, рідко можуть досягти адекватного рівня прихильності у лікуванні таких суспільно небезпечних хвороб, як ВІЛ, туберкульоз, вірусний гепатит. Після стабілізації фрізичного та психологічного стану у пацієнтів, залежних від опіоїдів, за допомогою замісних препаратів вдається забезпечити достатній рівень прихильності в значно більшій кількості випадків [11].

\section{Висновки}

1. На фооні замісної підтримувальної терапії у ВІЛінорікованих $\mathrm{ClH}$ знижується ступінь психотичних розладів 334 (31-45) до 27 (21-41) балів за шкалою BPRS і ступінь депресивних станів 314 (12-17) до 9 (7-14) балів за шкалою MADRS.

2. Зниження ступеня психотичних розладів і депресивних станів на фоні замісної підтримувальної те- рапії позитивно впливає на вірусологічну ефективність ВААРТ у ВІЛ-інфрікованих СІН.

3. Низьку вірусологічну ефективність ВААРТ можна прогнозувати у хворих на ВIЛ CIH при оцінці за BPRS більше 41 балу і/чи оцінці за MADRS більше 14 балів до початку лікування.

\section{Література}

1. Український центр контролю за соціально небезпечними хворобами МОЗ України. (2016). ВІЛ-інсрекція в Україні (№45). [Інформаційний бюлетень].

2. Zimmerman, M., Chelminski, I., MeGlinchey, J.B. (2008). A clinically useful depression outcome scale. Compr. Psychiatry, 49(2), 131-140.

3. Chawarski, M.C., Mazlan, M., Schottenfeld R.S. (2011). Behavioral drug and HIV risk reduction counseling (BDRC) with abstinencecontingent take-home buprenorphine: a pilot randomized clinical trial Drug Alcohol Depend. J. Infect. Dis., 204, (6), 12-15.

4. Wolfe, D., Carrieri, M.P., Shepard, D. (2010). Treatment and care for injecting drug users with HIV infection: a review of barriers and ways forward. Lancet, 31, 355-366.

5. Mathers, B.M., Degenhardt, L., Ali, H., Wiessing, L., Hickman, M., Mattick, R.P. ... Strathdee, S.A. (2010). Reference Group to the UN on HIV and Injecting Drug Use. HIV prevention, treatment, and care services for people who inject drugs: a systematic review of global, regional, and national coverage. Lancet, 20, 1014-1028.

6. Schaub, M., Chtenguelov, V., Subata, E., Weiler, G., Uchtenhagen, A. (2010). Feasibility of buprenorphine and methadone maintenance programmes among users of home made opioids in Ukraine. Int. J. Drug Policy, 21, 229-233.

7. Lachar, D., Bailley, S. E. (2011). New subscales for an anchored version of the Brief Psychiatric Rating Scale: Construction, reliability, and validity in acute psychiatric admissions. Psychological Assessment, 13, 384-395.

8. Клінічний протокол антиретровірусної терапії ВІЛ-інфекції у дорослих та підлітків, Наказ МОЗ України 551 (2010)

9. Todadze, Kh., Mosia, S. (2016). Dynamics of opioid substitution treatment in different initial substance user opioid dependent patients. Georgian Med. News, 254, 56-61.

10. Spire, B., Lucas, G.M., Carrieri, M.P. (2007). Adherence to HIV treatment among IDUs and the role of opioid substitution treatment (OST). Int. J. Drug Policy, 18(4), 262-270.

11. Roux, P., Kouanfack, C., Cohen, J. (2011). Adherence to antiretroviral treatment in HIV- positive patients in the Cameroon context: promoting the use of medication reminder methods. J. Acquir. Immune Defic. Syndr., 57, (1), 40-43.

\section{PSYCHOTIC AND MENTAL DISORDERS AND EFFECTIVENESS OF ART IN HIV- INFECTED INJECTION DRUG USERS}

\section{D.H. Zhyvytsia, V.H. Kazeka}

Zaporizhzhia Medical Academy of Post-Graduate Education Ministry of Health of Ukraine

SUMMARY. In HIV-infected injecting drug users (IDUs) related mental disorders are often diagnosed (35-50\% of all patients). Methadone and buprenorphine substitution maintenance therapy (SMT) is a powerful 
element of HIVIAIDS prevention. Antiretroviral therapy (ART) is an integral part of medical care for HIV-positive patients.

The aim of our study was to evaluate the impact of psychotic and mental disorders on the effectiveness ART in HIV-infected IDUs with substitution therapy. In the study we included 33 HIV-infected injection drug users, with evaluation degree of mental and psychotic disorders by BPRS and MADRS scales before SMT, ART and after 24 weeks of treatment.

Against the background of SMT to initiation of ART in all patients was marked reduction in the intensity of psychotic and depressive disorders, and after 24 weeks of ART reduction rate reached 12 points for the BPRS, and 6 points on the MADRS, respectively.

After 24 weeks of ART in 25 (75.8\%) patients had achieved a complete suppression of HIV (HIV-RNA $<50$ copies / ml). In 8 (24.2\%) patients had virological registered inefficiency ART. The degree of psychotic and mental disorders on scales in patients with virological ineffectiveness before the appointment of ART was significantly higher than in patients who achieved complete viral suppression, and reached $43(41,5-46,5)$ scores by BPRS, and $16(14-17,5)$ points by MADRS. The majority of patients with psychotic disorders (more than 41 points for BPRS) and / or depressive disorders (more than 14 points on MADRS) did not achieve virological efficacy after 24 weeks of treatment ART. The SMT in HIV-infected IDUs decreased level of psychotic disorders and depression and has positively affects on the virologic effectiveness of ART. Low virological efficacy of ART can be predicted in HIVinfected IDUs in the evaluation on BPRS scores over 41 and / or MADRS score by more than 14 points.

Key words: HIV infection, ART, CD4 cell, methadone, buprenorphine, injecting drug users.

Отримано 25.08.2016 p.

\section{КЛІНІЧНІ ТА ІНФЕКТОЛОГІЧНІ ОСОБЛИВОСТІ ХВОРИХ 3 РЕЦИДИВНОЮ АКТИВОВАНОЮ ГЕРПЕТИЧНОЮ ІНФЕКЦІЮ 1/2 ТИПУ ТА БЕЗПЛІДДЯМ}

Львівський національний медичний університет ім. Данила Галицького, Львівський обласний клінічний діагностичний центр

Обстежено 120 хворих з рецидивною активованою герпетичною інфекцією 1/2 типу, серед яких безпліддя було діагностоване у 63 пацієнтів. Виявлено, що клінічні прояви рецидивної інфекції вірусу простого герпесу (ВПГ) 1/2, особливо дерматологічного характеру, найбільше виражені у безплідних хворих, для яких були характерні часті рецидиви ВПГ 1/2, наявність ДНК ВПГ 1/2 у всіх досліджуваних клінічних зразках (слині, крові й зскрібках з місць уражень) та підвищені титри IgG у сироватці крові.

Ключові слова: простий герпес, клініка, рецидив, безпліддя.
Існування інсрекції в організмі жінки або чоловіка $є$ однією із серйозних причин безпліддя, яке вивчається і лікарями-практиками, і величезними науковими інститутами в різних країнах: ведуться спостереження, створюються спеціальні програми. Статистичні дані ВООЗ свідчать, що з проблемою безпліддя за весь репродуктивний період життя стикається до 8 \% подружніх пар у всьому світі [1-3]. У більшості випадків причини безпліддя залишаються невідомими [4]. Існує все більше доказів того, що вірусні інорекції відіграють певну роль в патогенезі чоловічого і жіночого безпліддя [2, 3, 5]. Серед мікроорганізмів, які колонізують у чоловічих і 